\title{
Reconstructing Parents' Meetings in Primary Schools: The Teacher as Expert, the Parent as Advocate and the Pupil as Self-Advocate
}

\section{GILLIAN INGLIS ${ }^{1}$}

$\approx \quad$ The efficacy of parents' meetings in primary schools in the UK is an area in need of research. This article uses an approach informed by grounded theory to explore the experiences and satisfaction of parents, teachers and pupils regarding bi-annual meetings to discuss pupil progress. A two-phase approach was utilised, with diary-interviews with parents and teachers and group pupil interviews in Phase 1, followed by a parents' questionnaire in Phase 2 derived from Phase 1 data. The findings from a doctoral study provide an overall more positive depiction of these meetings compared to existing research in the secondary sector. A model of the teacher as the expert and information-giver persists, but a consumerist ideology appears evident as parents seek to participate and advocate on behalf of their child. As parents become more proactive and teachers act to retain their professional authority, the interaction of the professional and advocate has excluded the perspective of the child. This leaves pupils in search of self-advocacy at meetings in which they are the object of discussion, but cannot be present. While pupils generally favour involvement, adults express a protectionist perspective on pupil exclusion with exceptional factors indicated as being the age of the child and the content of the meeting.

Keywords: Advocacy, Parents' meetings, Parents' evenings, Pupil participation

1 School of Education, University of Strathclyde, Glasgow, UK

g.inglis@strath.ac.uk 


\section{Prenova sestankov s starši v osnovni šoli - učitelj kot strokovnjak, starši kot zagovorniki in učenec kot samozagovornik}

\section{GiLLIAN INGLIS}

$\propto$ Učinkovitost sestankov s starši v osnovnih šolah v Veliki Britaniji je treba raziskati. $\mathrm{V}$ prispevku so na osnovi utemeljene teorije proučevani izkušnje ter zadovoljstvo staršev, učiteljev in učencev s sestanki, ki glede učenčevega napredka potekajo dvakrat letno. Uporabljen je bil dvofazni pristop: v prvi fazi so bili analizirani dnevniški zapisi staršev in učiteljev ter skupinski intervjuji $\mathrm{z}$ učenci, v drugi fazi pa je bil na osnovi podatkov iz prve faze pripravljen vprašalnik za starše. Ugotovitve iz doktorske raziskave $\mathrm{v}$ splošnem prinašajo nekoliko bolj pozitivno podobo teh sestankov $\mathrm{v}$ primerjavi $\mathrm{z}$ obstoječimi raziskavami $\mathrm{v}$ sekundarnem šolstvu. Model učitelja kot strokovnjaka in posredovalca informacij ostaja, vendar je pri starših očitna porabniška ideologija, saj želijo sodelovati in zagovarjati svojega otroka. S tem ko postajajo starši bolj proaktivni, učitelji pa želijo obdržati svojo strokovno avtoriteto, se $\mathrm{v}$ interakciji med strokovnjakom in zagovornikom izgublja vidik otroka. Zato želijo učenci na sestankih, na katerih se razpravlja o njih, svoj vidik predstaviti s samozagovorništvom, a jim prisotnost na sestankih ni dovoljena. Večina učencev odobrava vključenost, odrasli pa jih v želji, da jih zaščitijo - zaradi dejavnikov, kot sta starost otroka in vsebina sestan$\mathrm{ka}-$, iz sestankov izključujejo.

Ključne besede: sestanek s starši, večeri za starše, zagovorništvo, participacija učenca 
This article provides an overview of the findings of a study into the effectiveness of parents' meetings in Scottish primary schools. These are known elsewhere as 'parents' evenings' or 'parent-teacher conferences'. The study arose from the author's work with qualified primary teachers in which discussions indicated their overt and covert strategies to avoid face-to-face contact with parents. In these circumstances, the only guaranteed contact of this type will be through the contractual obligation of teachers to attend parents' meetings to discuss pupils' progress. This paper considers the roles that parents and teachers assume in these meetings and the extent to which this satisfies their expectations. Their working relationship is analysed using a model for parental involvement developed by Hornby $(2000,2011)$. The role of pupils in a traditional meeting model and the reactions of the participants to their potential participation are discussed.

\section{The context of the study}

\section{The educational context}

Scottish primary teachers are predominantly educated to teach children from 3 to 12 years of age, with the assumption that their skills will extend to include working with parents. With 'Reporting 5-14' (SOED, 1992), they received the first widespread advice on constructing parents' meetings; building on the written reporting process, it described two-way communication and joint decision making. The Parental Involvement Act (2006) was followed by further advice in the Parents as Partners Toolkit (SEED, 2006). Recently, Building the Curriculum 5 (2011) has extended the expectation to include pupils in the assessment and reporting process. In reality, the majority of primary schools maintain a traditional model of parents' meetings that excludes pupils.

\section{The theoretical context}

A literature search revealed that research into parents' meetings in the UK context has been predominantly about secondary schools (Clark \& Power, 1998; Maclure \& Walker, 1999; Power \& Clark, 200o; Walker, 1998). These studies depict widespread dissatisfaction with the meetings' lack of dialogue and appear to be repetition of the written report (Clark \& Power, 1998); these reports were difficult for parents to access for meaning as they were often 'vague and formulaic' (Power \& Clark, 200o, p.36). Where parents tried to contribute information regarding their child, there was the perception that it was not treated credibly by teachers. The organisation of these meetings in an open setting provided little confidentiality for open dialogue (Walker, 1998). 
Walker (1998) provided a picture of an event that is strongly managed by the teaching profession. Hornby (2011) outlined a variety of models of working with parents that describe different underlying 'assumptions, goals and strategies' (2000, p. 17). In the 'protective model' the parent and teacher assume separate roles that do not involve the parent in school education. The parent prepares the child to be sent to school and further involvement is not encouraged. Elsewhere, Crozier (1999) likened this to a 'division of labour' and suggested that it is more prevalent with working class families. Russell and Granville's (2005) study in Scotland found a perception in some parents that preparation of their child for school, such as providing food and clothing, is the extent of their involvement; that their supporting their child's education need not require further interaction with the school. Hornby states that the most prevalent approach in schools is the protective model. While the 'expert model' allows for contact, the teacher assumes expertise on the child's education. There is an assumption that parents are unable to express a credible viewpoint and have little capacity to support their child's education.

Two models engage parents as an educational resource. The 'transmission model' expects a parent to support aspects of their child's learning and to support the school's goals. A common example is asking parents to listen to reading homework. The parent is not expected to have a viewpoint and the professional communicates enough information on pedagogy in the expectation the parent will comply. However, in the 'curriculum-enrichment' model, there is an acknowledgement by the professional that the parent holds an expertise. An example may be asking a parent with a scientific background to lead classroom experiments. The parent is still engaged at the behest of the teacher.

In Hornby's 'partnership model', parents and teachers have the opportunity to equally bring their strengths to bear in supporting education. Hornby characterises this as two-way communication, mutual support, joint decision making and enhancement of learning. Across these models, we see an arc of power that shifts from the professionally dominated, towards some equity and on to a shift towards parent power in the 'consumer model. The parent is regarded as a consumer of education as a service; in Scotland, it is the parent who is recognised in education as the 'client'. A series of education acts in the 1980 and 199os, sought to further the philosophy that education should be open to market forces. Parents were encouraged to assume a proactive role that promoted professional accountability. Elsewhere, it has been debated as to whether this extended democracy or whether the influence of social capital meant that some parents were more able to engage with this philosophy and exercise its powers (Reay, 2005; Crozier, 2001). 
To place the consumerist model in the context of parents' meetings, where parents have been repositioned as 'clients', their role as expert regarding their own child is downplayed (Walker, 1998). As the consumerist paradigm has influenced education, the teaching profession has adopted an approach to parents' meetings that is akin to a 'public relations exercise' (Clark \& Power, 1998, p. 48). Maclure and Walker's (1999) analysis of parents' meetings drew parallels to information management strategies in other professions. Thus, the existing research depicted a blend of consumerism and professionalism, so that Walker (1998) concluded these were 'an ambiguous mix of social event and business meeting' (p. 174).

During the mid-1990s, the UN Convention on the Rights of the Child began to influence legislation through the Children (Scotland) Act (1995) and Standard in Scotland's Schools, etc. Act (2000). The influence upon pedagogy included the promotion of education for citizenship (McGettrick, 2001). In the context of parents' meetings, while Maclure and Walker (1999) reported examples in which secondary pupils were permitted to attend, many chose not to so as to avoid potentially stressful situations.

\section{The methodological approach}

As parents' meetings in the primary school emerged as an unexplored area, a research approach was adopted that was informed by grounded theory (Strauss \& Corbin, 1998). Three schools in the central area of Scotland participated; these are referred to as Gateway, Hill and Burgh and represented areas that were average or below average in national levels of income. All necessary ethical procedures were followed to ensure that informed consent and confidentiality were achieved for participants.

While participation in meetings would appear to provide direct information, this was discounted as the relatively short duration afforded little time for participants to adjust to the researcher. Instead, a diary-interview approach was selected as 'an approximation to participant observation' (Burns, 2000, p. 439). In the first phase of the study, three teachers volunteered at each school and two parents' names were randomly selected from their class roll. In reality, nine teachers and 15 parents took part. They kept a semi-structured diary that captured their actions before, during and after the second parents' meeting in the year. Following content analysis, the diaries informed the semi-structured interview schedules. In addition, the researcher completed a broad observation of the meetings and undertook a group interview of a mixed-age sample of six pupils at each school. 
A second phase of data collection followed in which a larger sample of parents at each school completed a questionnaire. There was an overall return rate of 92 questionnaires with a reasonably even split between schools. The questionnaire items were derived from the key findings of Phase 1 . This data was analysed using SPSS. While this allowed the researcher to check the reliability and validity of Phase 1 findings, the overall data analysis was an iterative process, as one returned to Phase 1 data to illuminate questionnaire results.

\section{Teacher as expert}

\section{A shared expectation of the teacher as expert}

While probing parent, teacher and pupil expectations, it emerged across the participants that the key purpose of parents' meetings remained that they exist to allow the teacher to transmit information on the pupil. In Phase 1, this was the main answer from pupils and the purpose cited by most teachers. Phase 1 parents had a high expectation of this purpose and Phase 2 parents mainly agreed that the teacher should lead the conversation.

The findings of this study suggest that parents' meetings fall within Hornby's (2011) 'expert model' whereby the teacher is the expert who disseminates information to the parent. This article will aim to argue that parents' meetings shift across Hornby's model to show influences of the 'protective model' and the 'consumer model' as well. In contrast, Building the Curriculum 5 describes a 'partnership model', including two-way exchange of views on the child's progress. However, the study did not find consistent application of this model in the primary school context.

As the expert, the teacher assumes authority in setting the agenda and deciding the valid issues during the parents' meeting. Hornby (2011) identified professional attitudes as potential barriers in work with parents; the corresponding attitude that appears mainly to underpin the expert model is that 'parents are less able' (less able than teachers to observe, perceive and understand information about their child's learning), allowing the teacher to choose to dismiss parental information. Where parents are unwilling to accept the expert view, attitudes that may appear include 'parents as problems' (parents viewed as problematic where they do not agree with the professional's viewpoint) and 'parents as adversaries' (teachers see conflict as inherent to the relationship with parents).

As the main expectation that teachers will transmit information reinforces their expert role, teachers in Phase 1 were the main group that perceived a purpose of parents' meetings in seeking information about the pupils' social 
context. The study suggests that implicit judgements are made about families within a relatively short space of time. These are unlikely to be made neutrally, thereby contributing towards teachers' attitudes to parents. One father was criticised by a Hill teacher for participating in the study as he was perceived as not showing interest due to previous non-attendance as meetings. The researcher's visit to the home found that the family had been under stress due to rehousing from another part of the UK, recent parental separation and unemployment. In the interview, the father spoke with enthusiasm about his children's education and revealed his personal disappointment at not completing university.

During the study, the judgements of some teachers reinforced the professional attitude of 'parents as causal' identified by Hornby (2011), that is, they have poor parenting skills. For example, one teacher linked a child's behaviour change to the father returning after a period of parental separation. Her views of the Hill parent were mixed:

And dad did appear... shall I put it this way, rather a rough, tough, scruff from the street but, when you actually spoke to him, he was giving you the most sensible feedback.

It would be misleading to conclude that the participants perceived in this study the sole purpose of parents' meetings being for teachers to transmit information. Parents having a goal of seeking their own information and the aim of achieving a consensus were strongly represented. Clearly, the traditional expectation that parents attend to hear about their child from the professional teacher persists, but it is being challenged by other expectations.

\section{The teacher adopts the role of expert}

In investigating what happened during the meeting, content analysis generated the category 'teachers' roles'. Across Phases 1 and 2 of the study, the dominant answer was that the teacher was an information-giver. Over two thirds of Phase 2 parents also indicated that the teacher gave advice during the meeting. Both of these roles support the teacher as expert. Teacher roles that place the professional in a less authoritarian role, such as listening to parents and answering their questions, were disproportionately represented in Phase 1. Phase 2 parents indicated greater use of these roles by teachers; while $97 \%$ said the teacher provided progress information, the next most popular role was answering specific parental questions (89\%), again suggesting that traditional models persist at parents' meetings but that they are being currently tested. There was a significant difference between schools, with Burgh teachers tending to adopt a more limited range of behaviours and an expert model. 
In the study, respondents rarely perceived a singular role for the participants. However, the balance and range of roles varied between parents' meetings. Parents criticised cases in which teachers assumed the singular role of expert as this led to a monologue, leading some parents to question the purpose of their attendance.

It's all black and white because the day's black and white, it's all kind of regimented - this is what we do - and it's as quickly as they can tell you exactly what's happening and out the door.

Elsewhere a parent suggested such teachers may as well write their opinions in a letter rather than have a meeting. Dyches, Carter and Prater (2012) advise strongly against teachers lecturing parents at meetings. Parents' responses on their satisfaction with parents' meetings proposes that this varies between individual teachers rather than being purely about models of practice at each site. Where parents cited more positive experiences, they had perceived that there was a balance and flow to the discussion.

\section{Preparation and professionalism}

The outcomes of the study indicate that the 'teacher as expert' view persists but this tradition is not uncontested. Many parents seek more proactive roles in the process and it is argued that the autonomy of the teaching profession has been eroded through a technical model of practice (Patrick, Forde, \& McPhee, 2003). Hannay (1993) argued that teachers maintain greater autonomy in private practice that has not been open to policy or legislation: this is achieved through a bureaucratic approach to meetings including in their preparation. All the participating teachers recorded methods of preparation for parents' meetings, with the dominant approaches including the creation of paperwork (making notes) or the collation of information on pupils through existing paperwork (reports, assessment records and pupils' work). In practice, parents have limited access to the same paperwork, as children's work was not uniformly available and some schools had moved to a meeting prior to the written report. In the absence of a school report, parents relied on more informal methods, such as talking to the child. Where meetings gave parents an opportunity to view pupil work, a teacher argued that the amount of work to be digested in a limited time was a disadvantage to the parent.

While schools varied in the sharing of paperwork, it could be argued that the key point here is not whether parents have access to the same documentation, but how the school facilitates parents having meaningful time and an environment to assimilate its contents. It should be considered that, for some parents, 
access and time may not be enough to provide an equitable preparation to the professional, as the literacy levels and degree of confidence in dealing with professional papers, such as assessment records, will vary.

The professionals in the study maintained the expert role through their preparation. Several teachers reported dissatisfaction when they had felt unprepared for parents' meetings. This experience was rarely extended to consider the parallel experience of the parent as few teachers in Phase 1 discussed the expectation that parents prepared for the meeting. Nearly three quarters of the Phase 2 parents recorded that the teacher used notes during the meeting. The argument is not that teachers should not use notes, but that schools should reflect on the power imbalance created in the expected preparation for teacher, parents and pupils.

Further, teachers need to reflect on how they make use of these notes during the meeting. The majority of Phase 1 and 2 parents recorded high rates of satisfaction with these meetings. However, Phase 1 parents could cite other experiences of parents' meetings that were less positive. Several parents criticised teachers giving a 'spiel' so that the notes served as a prepared speech. Since several teachers discussed the stress of early experiences of meeting parents, and eight out of nine teachers had no formal training in this area, it is understandable that they may deal with their discomfort by relying upon their preparation. The difficulty here lies in the potentially authoritarian image of the teacher that may be transmitted to the parent. Parents in Phase 1 expressed positive views where teachers' personalities and interpersonal qualities were communicated during the meeting, likening this to being 'with the people next door'. During Phase 1, two teachers identified a positive strategy in student teachers being encouraged to attend parents' meetings during school placement. This has the potential to overcome inexperienced teachers' reservations in meeting parents. How this strategy is supported in the school, including encouraging an open-minded approach to this practice and avoiding introducing teachers at a formative stage to negative professional attitudes towards parents, should be considered.

Overall, the findings support Walker's finding (1998) that teachers continue to hold the props of power at parents' meetings. Teachers need to consider how preparation can facilitate a dialogue rather than create a barrier to communication.

\section{Organising to safeguard the role of the expert}

The nature of the meeting organisation was set by each school. The data suggested various overt and covert ways that teachers organise to safeguard their roles as experts through elements such as setting, confidentiality, duration and timing in the school session. 
Setting, confidentiality and access to pupil work: Burgh teachers set up tables in the school hall to meet parents due to perceived security risks. This was mentioned in Phase 1 by parents as reducing confidentiality at the meeting. Phase 2 parents were more critical about the setting in Gateway, where the school layout led some teachers to have parents viewing work in the classroom while they conducted meetings; the varying settings in a school possibly raised parental awareness that more confidential meetings were possible. Phase 2 parents perceived the greatest confidentiality at Hill school where individual meetings were held privately in classrooms with pupil work available outside. This affected what parents were prepared to discuss and how comfortable they felt viewing pupil work before and after the meeting while other parents were present. In this open setting, it is reasonable to conclude that parents are less likely to challenge the teacher as expert or for an honest dialogue.

Phase 2 parents in Burgh were significantly more dissatisfied as they did not get access to their children's work. Again, where parents have limited access to their child's work, they may feel less prepared to engage with the teacher's remarks during the meeting. At Burgh, some teachers used children's work as a part of a deficit model of meeting parents, that is, to show parents what pupils could not do. All the sites followed tradition in that, where children's work was available, it was displayed at the meeting. There is potential for schools to consider whether this gives meaningful access to a range of pupils' work in a confidential setting, where parents can prepare themselves to meet with the teacher. Some of the pupils in Phase 1 suggested a potential role for themselves in attending the meeting and showing the work to their parents: this has potentially positive implications for the development of ethos and citizenship in schools.

Time, timing and amount: The schools set the time of the meetings but Phase 1 data revealed that teachers decide the actual duration. Here the study suggested an 'unwritten contract' in which the parent and professional believed that the teacher would give as much time as was needed. This belief was founded on a deficit model of the purposes of parents' meetings, whereby the meetings served little purpose for the parents of children who were progressing well at school, but longer meetings were held when children had difficulties. A Gateway parent summed this up:

I feel happy when it's a short one and you know everything's fine. It's the long ones you have to worry about.

In some cases, meetings appeared to have lost purpose for able children; this needs to be reconsidered. Phase 2 parents generally did not feel rushed at the meetings. Where time was an issue, the study revealed it had an effect on 
the parent- teacher dialogue including parents having difficulty in participating, teachers having limited opportunity to encourage parents' input and meetings having a very narrow content focus.

The timing of the meetings in the session was decided by the school. Phase 1 participants were positive when schools had decided to change from the end-of-year report-meeting pattern as it provided time for reinforcement, thus, giving the meeting a real purpose and avoiding repetition by the teacher of the content of the report. Some parents were wary of an early first parents' meeting as they doubted the teachers' knowledge of their child at that point. This presented a threat to the role of the teacher as expert and one parent reported disregarding any professional information at this point. Aspects of timing varied in parental satisfaction; however, parental views were not the driving force as schools set the timing of the meetings in the year.

\section{Achieving satisfaction: the challenge for teachers}

The purpose and role of the teacher transmitting information may remain central to expectations and practice, but to what extent was the traditional expert approach sufficient to satisfy teachers, parents and pupils? In an expert model of parents' meetings, it could be expected that participants' highest satisfaction was achieved when the teacher gave positive feedback on pupil progress. While this was important to teachers, the interpersonal qualities of the teacher during the meeting were more important to parents and rated favourably with teachers as well; in particular, the merits of the teachers being perceived as knowledgeable about the child as an individual, being approachable and being honest.

Hornby (2000) stated that the parents have a 'hidden agenda' of finding out whether the teacher knows the child well; this appears to be supported here. This type of information cannot be communicated through formulaic reporting of assessment, as Hornby states that this is more likely to be conveyed through anecdotes on the child. Comments from Phase 1 parents agreed that feedback on children's interests and unique responses lead parents to trust the other judgements of the teacher. This was illustrated in a parent of a five-yearold child who received some negative feedback about her child's behaviour, but gave the meeting the highest rating for satisfaction. In this Burgh teacher, she saw someone who has 'a good understanding of what made him tick'. The teacher had conveyed this through her knowledge of the child's personal interest in nature. Achieving a good degree of knowledge requires that teachers regularly reflect on how they know each child as an individual, and take action to acquaint themselves with this information where it is not evident. The study 
suggests that parents bring their observations of the child to the meeting and look for areas of consistency with the professional's feedback.

Both parents and teachers raised the issue of teachers being perceived as honest. The literature states that parents in England found reports to be broad and unclear with parents uncertain on future action (Clark, 1998; Power \& Clark, 2000). This study suggests less confusion with the content of meetings, but some professionals were critical that positive written reporting led to disappointment at the parents' meetings as teachers attempted to put the reporting statements into context.

The level of satisfaction also resulted from the perceived approachability of the teacher. This study found that aspects that may be perceived as being professional by teachers, such as using notes and maintaining neutrality can be interpreted by parents as a lack of empathy or unwillingness to engage in a dialogue with the parent. It could be argued that, rather than suppressing individuality in the presentation of the role of expert, parents value teachers allowing their personality to show in these meetings. As stated, one parent likened this to chatting with a neighbour, allowing the parent to feel on an equal standing to the teacher. This proposes that caution must be shown in developing practice regarding parents' meetings: while policy may seek to provide equality of provision, it may reduce more sensitive aspects of teacher individuality that parents value and to which they can relate.

\section{Pupil self-advocacy: a challenge to professionalism}

The main expectations of parents' meetings support the model of teacher as expert but it has been argued that the consumer model has informed these meetings as the professionals prepare and feedback with a perception of parents as clients. Nevertheless, the challenge from the parent as active consumer is shifting them towards more proactive roles. As the teaching profession has adjusted since the 1980 s to the parent as advocate, it now faces a new challenge to the teacher as expert through the legislation and policy that supports greater pupil self-advocacy.

In Phase 1 of this study, both the teachers and parents had mainly negative or undecided responses to pupil participation at parents' meetings. Teachers supported a protectionist perspective on the child as they believed that absence protected the child from anxiety and low self-esteem. While Roche (1999) identified that acknowledging the right of the child to be consulted is counter to the professional culture, Rudduck (2002) proposed ways in which pupil participation in school could strengthen the quality of teachers' work by accessing the fresh perspective of the child. 


\section{Parent as advocate}

\section{The shift in parental expectations}

The study indicated that the teacher as expert remains dominant. However, as parents assume an advocacy role, other expectations are emerging. In Phase 1, the purpose that parents seek specific information was highly cited by parents. Phase 2 presented a less strong case for proactive behaviour in parents bringing their 'own agenda', suggesting that advocacy behaviour lies in being responsive during the meeting. Regardless, parents described a range of methods that they used to prepare before the meeting. The involvement of the child at this stage was generally to benefit the adult's preparation. Teachers need to consider the extent to which they conduct meetings in a way that permits parents to raise any questions that they have prepared.

Parents in Phase 1 were more likely than teachers to view parents' meetings as a mediation process in which the aim was to arrive at a consensus. In valuing this expectation, it follows that parents believe that their views of the child should be valued equally to those of the professional. This belief runs contrary to the perception of the teacher as expert.

While the relationship between the parent and teacher in the primary school context may be based on the professional spending more time with the pupil than in the secondary school, the literature that states that parents seek a social link to the teacher may be overstating its case (Clark, 1998). The social perspective had some support from Phase 1 participants, but Phase 2 parents were mainly neutral on this issue.

\section{Parents in search of a role}

Where the perception is that the teacher assumes the role of expert, passive roles might be expected for the parent. Such parental roles that Phase 1 participants described were supporting the school, listening to the teacher, and providing the teacher with social context information on the child. In this phase, more teachers expected parental support for the school and the provision of background information. Here, the teacher defines the needs to be met by the parent. Hornby (2011) described these clear roles as part of the 'protective' model of working with parents, while Crozier (2000) similarly describes teachers defining partnership by parents meeting the needs of the school.

The rise of the consumer model of education had charged parents with an advocacy role and increased professional accountability. The participants in this study described proactive parental roles that support this argument. Phase 
2 parents cited listening to the teacher as their main role during the meeting (97\%) but there was also a high incidence of parents asking questions (94\%) and expressing their views ( $87 \%)$. Parents also gave a good level of response to supporting their child at the meeting (79\%).

Phase 1 teachers were dissatisfied when parents did not participate during the meeting. However, some teachers described discomfort when they felt interrogated. This is exemplified by a parents' meeting at Hill where the teacher rated her satisfaction lower than the parent; while the parent was happy that her concerns had been addressed, the teacher was uncomfortable that she had to address a prior discipline issue that was raised. Parents were expected to be advocates for their child but they could have difficulty in judging a level of involvement at which they would not be judged as a 'problem' or 'adversary' (Hornby, 2011). Moore's (1994) research highlighted a clash in perceptions whereby what the parent sees as a query, the school may interpret as a complaint.

\section{The advocate: the role that unites and divides}

Crozier's studies $(2000,2005)$ conclude that equitable treatment for parents may not mean treating all parents equally. She found that class and ethnicity can have profound effects on parental expectations and their ability and willingness to exercise parental power under the consumerist philosophy of education. These factors were not examined in the present study. However, feedback from parents suggested that factors within the control of the school can affect the ability of parents to act proactively at these meetings. As previously discussed, these include the organisation of the meeting and the interpersonal qualities of the teacher. Some parents were able to prepare more fully for meetings and assume proactive roles. These often reflected their individual abilities whereas schools should aim to empower more parents by including approaches that encourage genuine parental input and by considering the differing support that parents may need to participate.

As the consumerist philosophy has arguably empowered some parents, it has also divided parents by their ability and willingness to assume the advocacy role. Debatably, disempowering parents reinforces the role of the teacher as expert. However, parents being without a genuine voice at parents' meetings leads to a monologue from the professional rather than a dialogue between interested and informed parties.

\section{Appraising the process}

The parent as advocate is supported by parental perceptions of satisfaction with parents' meetings. For Phase 1 teachers, the interpersonal qualities of 
the teacher at the meeting followed by the child making good progress were the main sources of satisfaction. However, Phase 1 parents favoured the interpersonal qualities of the teacher and the perception that a consensus was reached during the meeting. Phase 2 parents identified key teacher qualities and most agreed or strongly agreed that they had reached a consensus at the meeting. Phase 1 suggested that parents may not frequently and explicitly identify reaching a consensus as a purpose, but they are aware when they reflect on the meeting of whether they are satisfied that a consensus was achieved. To reach a consensus, the parent places equal value on his/her perception of the child in the reporting process. Following the meeting, many parents continued to take action to support their child. The parent and pupil descriptors of the content of feedback after the meeting matched in Phase 1. About half of the Phase 2 parents reported taking action including supporting their children and talking to the children about their progress. The findings of this study illuminate a practical example of how parent-teacher dialogue may lead to support for pupil learning being extended into the home environment.

\section{Pupil self-advocacy: a challenge to the new order}

The role of the parent as advocate is prompted and reinforced by the absence of the focus of these meetings: the pupil. The consumerist model has created a proactive role for some parents and they appear to be shifting their expectations and roles as parents' meetings in alignment with this philosophy. Parents have new expectations that include gaining specific information from the teacher, and they adopt roles that support this aim including asking questions and expressing their views. Phase 1 parents, in agreement with the teachers, were hesitant to move to complete pupil participation. An irony is suggested in this study in that some parents believe it is their role to mediate information to the child and that some pupils demonstrated awareness that information was mediated to them. However, a frequently cited parental reason to exclude pupils was the fear that parents would then have moderated information given to them by the teacher. Parents perceived that they were making progress in gaining access to the specific information that they wanted but they did not want to extend advocacy to children as they felt it would be detrimental to the gains in parental rights. These findings are consistent with the assertion of Prout (2000) that parental rights and pupil rights are often viewed as being in diametric opposition. Phase 2 parents were more likely to accept pupil participation in some form, but this still mainly depended on the type of information discussed at these meetings. 


\section{Pupils in search of self-advocacy}

\section{Limited expectations}

Pupils' expectations related closely to the answer to the current structure and content of parents' meetings. Pupils were not present at any of the parents' meetings in the study and this limited their perspective on what happened at the current meetings. In Phase 1, nearly half of the parents and a few teachers reported involving the child before the meeting; however, the pupil participants did not perceive of any preparation at this stage. Closer consideration of the type of involvement by parents shows that children were consulted before parents' meetings primarily to prepare the adult.

\section{Reinforcing the role of teacher as expert}

The second-hand experience of the pupils of parents' meetings led many to hold traditional expectations of these events. They saw the teacher's role as mainly to report information on their progress. They had little knowledge of what their parents did at these meetings. The pupils had a narrow perspective on the content of the meetings, believing that they focussed on their cognitive and social development only.

\section{Children as self-advocates at parents' meetings}

The current practice described in this study indicates that pupils' nonattendance at parents' meetings is due to a paternalistic or protectionist perspective by the adults. Franklin (2002) described children's welfare rights that protect them from perceived harm. Here, adults identify this harm as damage to the child's self-esteem and the creation of anxiety. A logical development of this is view is that adults believe that children are ignorant of the information about them that is discussed. In the study, pupils had a narrow perspective of content but they did know that their work and behaviour were reviewed. Further, some Phase 1 parents described talking to their child before the meeting to ask for a prediction of its content and for any issues that should be raised. It could be argued that there is a contradiction in parents believing that children are knowledgeable enough about their progress in school to prepare the parent but not aware enough to participate when these issues are discussed during the meeting.

Franklin (2002) also discussed children's rights of self-determination. The practice described in this study did not suggest that pupils' powers of selfadvocacy were enhanced: they reported little preparation before the meeting, they were excluded from the meeting and they had information mediated to them by adults after the meeting. 
The potential to participate was welcomed by the majority of pupil participants. The teachers and parents in Phase 1 were more hesitant, but the majority of Phase 2 parents were willing to participate in meetings with children present in some form. The key variables linked to participants agreeing to pupil participation were age and the issues being discussed. Roche (1999) argued that pupils' rights should increase with age. The adult participants in Phase 1 agreed that pupil participation was appropriate as pupils progressed through primary school. Alternatively, Phase 2 parents stated that the main variable in pupils attending would be the issues that were being discussed at the meeting.

When participants were asked to consider the role that pupils would have at a parents' meeting, the responses included expressing a viewpoint, hearing the views of the teacher or parent and identifying aspects of school work where they needed support. Pupils were able to suggest further roles, such as showing their work to the parent. The comparison of suggested roles indicated that pupils were looking to be actively involved, mainly through expressing their views, rather than having a non-participatory role. This has implications for the development of parents' meetings in that children must perceive that they have a meaningful participatory role in which they are to be genuinely engaged with the process.

Although the majority of the children in this study were positive about potential participation and they could envisage proactive roles for themselves, developments to support the right of the pupil to attend these meetings should be sensitive to potentially empowering and diminishing the child (Garner \& Sandow, 1995). To this end, adults would have to acknowledge the child's right to non-attendance (Walker, 1996). Maclure and Walker (1999) found that pupils were concerned that their presence would lead to a 'show trial' and the responses in the present study, particularly from Hill pupils, seemed to agree:

I wouldn't like to be there because, if I got a bad report, I'd probably get shouted at inside the school or something.

This indicates that such meetings need a shared purpose and agenda that respects the presence and views of all the participants.

\section{Thinking outside the box}

Clearly, when the researcher spoke to Phase 1 participants, the potential for pupil participation was more frequently interpreted as, 'How can we fit children into the current parents' meetings?' It is, therefore, understandable that Walker (1996) concluded that meetings would be longer and more complicated. Similarly, one can relate to why pupils fear a 'show trial' where the purpose and 
content of meetings indicated a deficit model. Alternative models of parents' meetings with pupil participation have been explored by writers such as Dyches, Carter and Prater (2012).

Where schools and parents are willing to consider the potential for pupils to engage as self-advocates, a fresh approach is needed for the structure and agenda of parents' meetings. This point was raised by some of the Phase 1 teachers. Participants need to reflect on the variety of purposes proposed by this study and start by considering a title for these meetings that genuinely reflects the expectations of parents, teachers and pupils. An innovative title that reflects purposes based on pupil, teacher and parent participation should help to define new roles for the participants. Sharing the agenda and potential roles in a meaningful way to parents and at an appropriate level to the stage and understanding of the child should help to reassure children that this meeting should contribute positively to their education; communicating to parents that they are not expected to chastise their child during the meeting to demonstrate that they are supportive parents. It should also indicate to professionals that they have a broad educational expertise to offer but they should listen and learn from the child and parent to support the education of their common interest - the child.

\section{Final considerations}

The justification for this study rested on a lack of research on parents' meetings in the primary school compared to the secondary sector; the data indicates comparatively higher parental satisfaction. However, the research impetus came from observations regarding personal contact between teachers and parents. Thus, the outcomes refer specifically to parents' meetings with some broader implications. It is questionable whether 'partnership' can be achieved in a 5-to-10-minute interview in which one participant holds more information on the child's educational progress. Perhaps it is more realistic to suggest that teachers will move towards a partnership model through consistently using a positive approach across a range of contacts with parents, of which parents' meetings are one.

In this study, including teachers in training in meetings was viewed positively. There needs to be a consistent exploration of working with parents that foster positive attitudes across Initial Teacher Education courses. In the one-year Induction Scheme that follows graduation, parents' meetings are often tackled; while it is important that novice teachers know what to expect, this study indicates they need to understand how to engage as parents highly valued teachers' interpersonal skills. Beyond the early professional stage, there is merit 
in staff evaluating their frequent 'private practice' of meeting with parents.

In the changed education setting of the 21st century, this study suggests that teachers need to re-evaluate the purpose of parents' meetings. During the last 50 years, Scottish primary education has experienced curricular and pedagogic change as it moved from the Primary Memorandum (1965), through the 5-14 Curriculum Guidelines (1991) to A Curriculum for Excellence (2004); regardless, the format of parents' meetings has remained constant. In this study, the duration and content of meetings indicated a drift towards a deficit model; the purpose for children progressing well was lost. The positioning of parents in relationship to the school has not remained static; the data shows that many parents seek a proactive role, but they can be frustrated when teachers do not engage with their views or hamper their ability to prepare meaningfully.

As A Curriculum for Excellence principles are embedded in practice, it reveals a professional focus on teacher responsiveness, curricular integration and pupil-led learning. It is hoped that its messages on teacher, parent and pupil engagement with assessment are not subsumed. Is it not incomprehensible that child advocacy is currently promoted through greater pupil engagement with school management, such as Pupil Councils, and their leadership in learning, through a revised curriculum, but the thread of consistency in thought is broken when it comes to reporting on pupil progress? After 50 years, the method by which pupil acheivement at primary school is shared deserves a review.

\section{References}

Burns, R. B. (200o). Introduction to research methods. London: Sage.

Clark, A. (1998). Parents voices in school reports. Advisory Centre for Education Bulletin, 83, 8-9.

Clark, A., \& Power, S. (1998). Could do better: School reports and parents' evenings. London: Research and Information on State Education.

Crozier, G. (1999). Is it a case of 'We know when we're not wanted'? The parents' perspective on parent-teacher roles and relationships. Educational Research, 41(3), 315-328.

Crozier, G. (200o). Parents and schools: Partners or protagonists? Stoke on Trent: Trentham.

Crozier, G. (2005). Beyond the call of duty: The impact of racism on black parents' involvement in their children's education. In G. Crozier \& D. Reay (Eds.), Activating participation: Parents and teachers working towards partnership. Stoke on Trent: Trentham.

Dyches, T. T., Carter, N. J., \& Prater, M. A. (2012). A teacher's guide to communicating with parents: Practical strategies for developing successful relationships. New Jersey, US: Pearson Educational, Inc. Franklin, B. (Ed.) (2002). The new handbook of children's rights: Comparative policy and practice. London: Routledge.

Garner, P., \& Sandow, S. (Eds.) (1995). Advocacy, self-advocacy and special needs. London: Frances 
Pinter.

Hannay, G. (1993). Socialisation and deviancy in Scottish primary schools: 1872-1993. Unpublished

M.Ed. thesis, University of Glasgow.

Hornby, G. (2000). Improving parental involvement. London: Cassell.

Hornby, G. (2011). Parental involvement in childhood education: Building effective school-family partnerships. London: Springer.

Maclure, M., \& Walker, B. (1999). Brief encounters of a predictable kind. Managing Schools Today, $8(9), 52-54$.

McGettrick, B. J. (2001, May 12). Valuing developing citizens. Retrieved from http://www.ngflscotland. gov.uk/earlyyears/latestnews.

Moore, C. (1994). Parents or pests? Experiences of grievance and redress procedures in education.

Edinburgh: Scottish Council for Research in Education.

Patrick, F., Forde, C., \& McPhee, A. (2003). Challenging the 'new professionalism': From managerialism to pedagogy. Journal of In-service Education, 29(2), 237-253.

Power, S., \& Clark, A. (2000). The right to know: Parents, school reports and parents' evenings. Research Papers in Education, 15(1), 25-48.

Reay, D. (2005).Mothers' involvement in their children's schooling: Social Reproduction in action?

In G. Crozier \& D. Reay (Eds.), Activating participation: Parents and teachers working towards partnership. Stoke on Trent: Trentham.

Roche, J. (1999). Children's rights, participation and citizenship. Childhood, 6(4), 475-493.

Rudduck, J. (2002). (Sept 2000). 'You've asked us if there's anything we'd like to change-but will it happen?: The transformative potential of consulting young people about teaching, learning and schooling. Paper presented at the Scottish Educational Research Association Conference, Dundee. Russell, K., \& Granville, S. (2005). Improving parental involvement in children's education. Edinburgh: Scottish Executive.

Scottish Government (2011). Building the curriculum 5: A framework for assessment. Edinburgh: Scottish Government.

Scottish Executive Education Department. (2006). Parents as partners in their children's learning toolkit. Edinburgh: HMSO.

Scottish Office Education Department. (1992). Reporting 5-14: Promoting partnership. Edinburgh: HMSO.

Strauss, A. L., \& Corbin, J. (1998). Basics of qualitative research: Grounded theory procedures and techniques ( $2^{\text {nd }} e d$.). London: Sage.

Walker, B. (1998). Meetings without communication. British Education Research Journal, 24(2), $163-178$. 


\section{Biographical note}

GILLIAN INGLIS, a former primary teacher, has taught at the University of Strathclyde for 13 years. She led its undergraduate degree in primary education, the largest course of this kind in Scotland. Her research and teaching interests lie in teachers working with parents, the focus of her doctoral study. An enduring interest in professional reflection and development drew her to lead a project in the Re-engineering Assessment Practices in Higher Education study (REAP) and she has published work with the Quality Assurance Agency In Higher Education on employability and personal development planning. 